\title{
Knowledge Workers Mobility in Innovative Organizations: The Role of Individual Differences
}

\author{
Mahmoud Ibrahim Fallatah ${ }^{1}$ \\ ${ }^{1}$ College of Business, Umm Al-Qura University, Saudi Arabia \\ Correspondence: Mahmoud Ibrahim Fallatah, College of Business, Umm Al-Qura University, Makkah, Saudi \\ Arabia. E-mail: Mifallatah@uqu.edu.sa
}

Received: June 6, 2019

Accepted: July 20, 2019

Online Published: August 5, 2019

doi:10.5539/ijbm.v14n9p23

URL: https://doi.org/10.5539/ijbm.v14n9p23

\begin{abstract}
The paper extends previous research on knowledge workers mobility by proposing that knowledge workers in innovative organizations have lower rates of mobility than those in other organizations. Further, I suggest that the extent to which knowledge workers in innovative organizations remain at their jobs depends on the personality of each worker. Drawing from the Big-Five model, I argue that knowledge workers who score high on extroversion and openness to experience are less likely to leave innovative organizations, whereas those who score high in agreeableness, conscientiousness, and neuroticism are more likely to leave such organizations. The paper offers some practical implications as well as some ideas for future research.
\end{abstract}

Keywords: Knowledge workers, mobility, Big-five model, innovation, personality, turnover

\section{Introduction}

Knowledge workers are a main source of competitive advantage for organizations (Barney, 1991; Pfeffer, 1994; Porter, 1985; Wright \& McMahan, 1992); hence, it is important for organizations to retain their skilled workers. However, while organizations strive to implement human resources policies that aim to reduce turnovers, mobility of knowledge workers is still one of the major problems organizations of all sizes and types deal with regularly (Mitchell, Holtom, \& Lee, 2001). The loss of knowledge workers affects organizations in multiple ways. First, when knowledge workers leave an organization, it loses the knowledge embodied within those workers (Cohen \& Levinthal, 1990, Corredoira \& Rosenkopf, 2010; Nonaka, 1994). Second, organizations incur direct and indirect costs such as administrative costs and wages for workers who are asked to fill in for departing employees (Mitchell et al, 2001).

Research on knowledge worker mobility and turnover has focused on antecedents and consequences of knowledge workers mobility. Consistent with the model of March and Simon (1958), the majority of research in the human resource literature indicates that job-satisfaction and ease of movement are the major determinants of turnover (e.g., Carsten and Spector, 1987; Dong et al, 2012; Lee, Mitchell, Holtom, McDaniel, and Hill, 1999; Mitchell et al, 2001). That is, knowledge workers are more likely to leave their current employers when they are dissatisfied and when job opportunities elsewhere make it easier for them to quit. Drawing on Denison and Mishra's (1995) framework of organizational culture, recent research also shows that knowledge workers mobility is influenced by the culture of the organization (Lee et al, 2018). As for consequences of losing skilled workers, the research asserts that turnover of knowledge workers is negatively related to unit-level performance (Hancock et al, 2013). A more recent research by Eckardt, Skaggs, and Youndt(2014) also finds that loss of knowledge workers is negatively associated with firm performance, especially in service organizations.

Research has also acknowledged that losing key knowledge workers increases the risk of organizational dissolution, especially when departing workers move to a neighbor organization (Wezel, Cattani, \& Pennings, 2006). Likewise, Phillips (2002) posits that organizations with high rates of knowledge work mobility are less likely to survive. While most research points to the negative impact on organizations that loses knowledge workers, some studies have also acknowledged the benefits of knowledge worker mobility for hiring organizations. For instance, studies have found that interfirm mobility of knowledge workers is key for transferring knowledge that organizations lack (e.g. Song, Almeida, \& Wu, 2003; Rosenkopf \& Almeida, 2003) 
Despite the growing literature of knowledge worker mobility, our understanding of the phenomenon is still limited. Specifically, little research has paid attention to individual factors that relate to antecedents and consequences of knowledge worker mobility. Consideration of individual differences is important in studying organizational phenomena as it provides contingency factors that make building of theories and conducting of empirical studies more informative. Recent research started to incorporate some contingency factors in the study of worker mobility. For example, building on the context-emergent theory, studies have examined factors that affect the relationship between collective turnover and unit performance (Nyberg \& Ployhart, 2013; Reilly, Nyberg, Maltarich, \& Weller, 2014). Yet, more individual, organizational, and environmental factors, among others, need to be contextually accounted for when studying knowledge worker mobility. For instance, we know little about what type of organizations are more likely to suffer from knowledge worker mobility. We also do not know much about individual factors that influence knowledge worker intentions to leave their organizations.

To close this gap and to contribute to the literature of knowledge worker mobility, the current paper proposes two contingency factors that could help predict mobility of knowledge workers. Particularly, I argue that knowledge workers in innovative organizations are less likely to leave their jobs. Furthermore, drawing on theories of person-organization fit (Tom, 1971) and vocational choice (Holland, 1973), the paper argues that the relationship between innovative organizations and knowledge worker mobility is moderated by individual differences. That is, based on the Big-Five model of personality, I argue that certain individuals are less likely to leave innovative organizations than others. It should be noted that knowledge worker mobility, in this paper, refers to situations where knowledge workers voluntarily decide to leave their organizations. This mirrors what human resource scholars term "voluntary turnover" (e.g. Shaw, Delery, Jenkins, \& Gupta, 1998), which is different than involuntary turnover in that the latter refers to situations in which employers make the decision to end an employee's association with the organization. The proposed model is depicted in Figure 1.

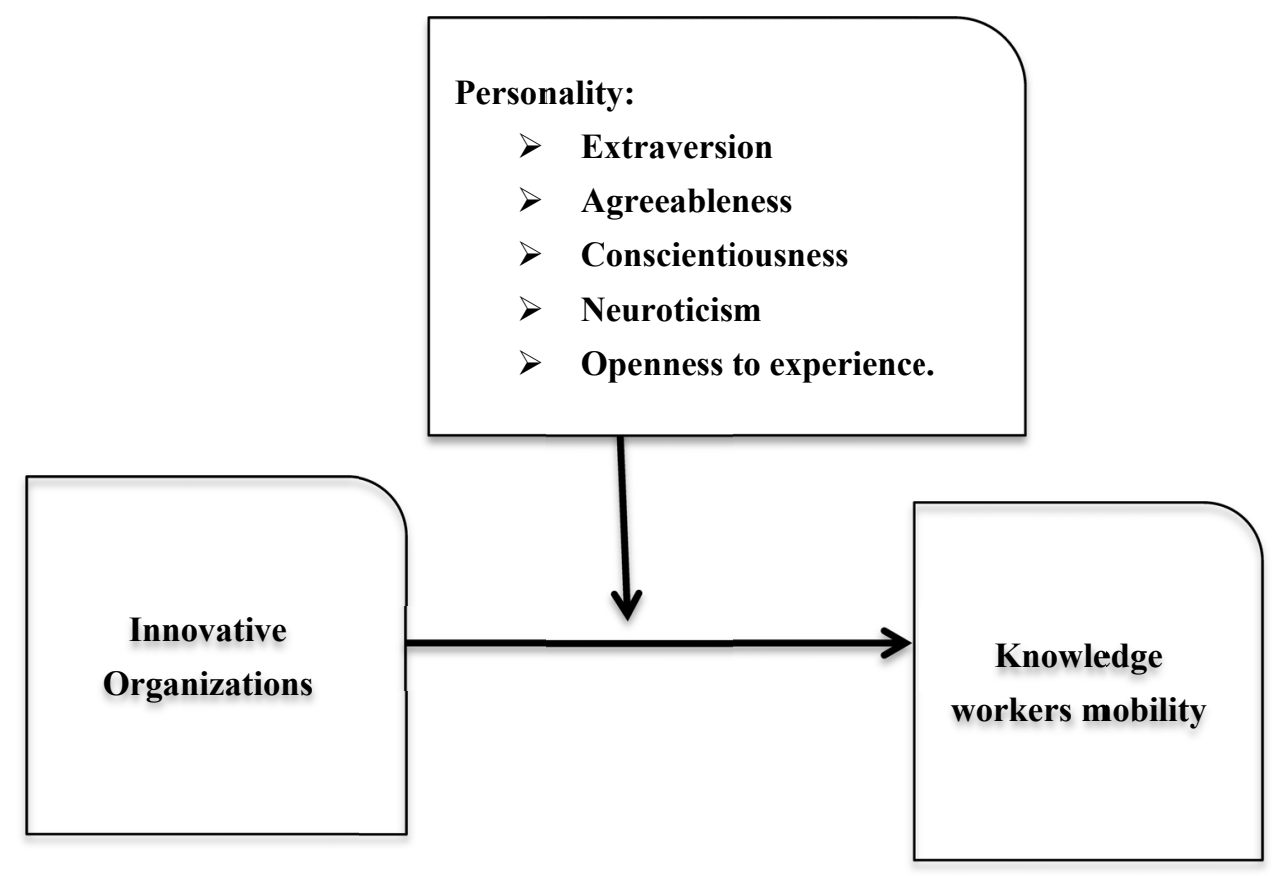

Figure 1. The Relationship between innovative organizations and knowledge workers mobility and the moderating role of individual differences (personality)

The rest of the paper is structured as follows. In the next section, I provide arguments on how knowledge worker mobility in innovative organizations tends to be lower than in other organizations. Then, I build on the Big-Five model to address the moderating role of individual differences. Finally, I conclude with discussions about practical and research implications. 


\section{Theoretical Background and Propositions Development}

\subsection{Innovative Organizations and Knowledge Workers Mobility}

The impact an organizational culture has on knowledge workers mobility is well established. Research shows that the level of knowledge workers' commitment to an organization is partially influenced by the organization's culture (Lee et al, 2018). Thus, the current paper suggests that an organization with an innovative culture is more likely to retain its knowledge workers.

Organizations pursue innovation to differentiate themselves in competitive markets to gain a competitive advantage (Porter, 1985). They regularly develop new products, services, or processes to satisfy customers' needs and make profits (Damanpour, 1991; Teece, 1986; 2006). In innovative organizations, knowledge workers; defined as individuals who process information rather than physical goods (Von Nordenflycht, 2010), are of high importance. Working in knowledge-intensive environments (Alvesson, 2000), knowledge workers are the "champions" who generate ideas and create new knowledge to produce new product or services (Galbraith, 1982). Therefore, innovative organizations strive to provide their knowledge workers with an environment and culture that facilitate the process of generating and exchanging new ideas (Lertxundi, Barrutia, \& Landeta, 2019). In turn, knowledge workers usually value such an environment that enables them to apply their skills (Hamel and Breen, 2007). Thus, they tend to have higher job satisfaction and lower intentions to leave the organization (Griffeth, Hom, \& Gaertner, 2000; March \& Simon, 1958).

In fact, the literature posits that innovative organizations have unique features that tend to make them more likable than other organizations (Dougherty and Hardy, 1996; Hamel and Breen, 2007). For example, employees in innovative organizations enjoy the benefits of the unique human resource (HR) system of such organizations (Bretz \& Judge, 1994). HR systems refer to the collection of policies and procedures that delineate how particular HR functions are practiced in a specific organization (Bretz, Ash, \& Dreher, 1989). Scholars emphasize two HR systems-- control HR systems and commitment HR systems (Arthur, 1994). In control HR systems, the goal is to reduce direct labor costs, or improve efficiency, by enforcing employee compliance with certain organizational rules and basing employee rewards on measurable output criteria. On the other hand, in commitment HR systems, the focus is on developing committed employees who can be trusted to use their discretion to carry out job tasks in ways that are consistent with organizational goals. Thus, I predict that the commitment system, with the discretion it gives to individuals, is more likely to be employed by innovative organizations. Commitment systems, according to Arthur (1994), are characterized by higher levels of employee involvement in managerial decisions, formal participation programs, training in group problem solving, socializing activities, and highly skilled workers. The relationship between HR systems and turnover is well documented in the literature (e.g. Huselid, 1995). For example, research asserts that workers in organizations with high levels of work involvement exert more efforts (McClean \& Collins, 2001) and have higher organizational commitment and; thus, are more likely to stay at their current jobs (Guthrie, 2001). In this paper, I argue that knowledge workers in innovative organizations tend to have higher organizational commitment and are less likely to leave their organizations.

In addition to employing commitment HR systems, innovative organizations are usually structured in a unique way that facilitates innovation processes (Galbraith, 1982; Hamel \& Breen, 2007). In order to innovate, employees are provided with a decentralized environment in which interactions among knowledge workers and functional departments are encouraged. This reflects an environment of trust and cooperation among knowledge workers, which facilitates knowledge creation and transfer (Collins \& Smith, 2006; Teece, 1996; Tsai, 2001). In such an environment, "champions" could voice their ideas to "sponsors" who have the authority to take them further in order to, eventually, launch a new product or service (Galbraith, 1982; Howell \& Higgins, 1990). Indeed, Dougherty and Hardy (1996) find that high levels of interactions among functional departments lead to more product innovation. In addition, because innovative organizations are more likely to be involved with international sources of innovation such as offshoring (Mihalache, Jansen, Van Den Bosch, \& Volberda, 2012) or international strategic alliances (Afuah, 2003), decentralization becomes even more important due to the physical separation among business units. Hamel and Breen (2007) believe that environments with such characteristics offer more freedom to employees to think and to be creative. I predict such encouraging environments to be viewed favorably by employees, in contrary to centralized work environments, which tend to increase turnover among workers (Kwon et al., 2012).

Other positive working conditions in innovative organizations also contribute to the retention of skilled knowledge workers. For example, the amount and quality of technical training that workers typically receive in innovative organizations should motivate them to remain at their current jobs. To explain, innovative 
organizations usually aim to create new knowledge to foster their innovativeness (Almeida \& Phene, 2004; von Krogh, Ichijo, \& Nonaka, 2000). The literature suggests that organizational knowledge resides within individuals (Kogut \& Zander, 1992; Nonaka, 1994; Polanyi, 1962). Hence, workers in innovative organizations are expected to be involved in substantial technical training programs to keep up with evolving technologies (Anderson \& Tushman, 1990; Chow \& Gong 2010; Collins \& Smith, 2006). Chow and Gong (2010) argue that a knowledge-based human resource system that provides more technical training is positively related to innovation. Hence, employees in such organizations are thought to be enjoying an environment where they could regularly develop their skills and knowledge.

Another significant attractive factor in innovative organization is related to rewards. Research asserts that rewarding is a huge source of motivation for workers (Rynes, Gerhart, \& Minette, 2004). It has also been suggested that pay dissatisfaction is one of the major reasons that force workers to leave their organizations (Griffeth et al, 2000). Reward systems such as those based on creating values or generating ideas are common in innovative organizations (Hamel \& Breen, 2007). I expect similar systems to increase workers' loyalty and to decrease chances of knowledge workers mobility.

The aforementioned working conditions shape the overall culture of innovative organizations. The literature indicates that positive organizational culture impacts employees' commitment to the organization and reduces their intentions to leave (Abbas, Raja, Darr, \& Bouckenooghe, 2014; Sheridan, 1992). This phenomenon is better explained by social identity theory, which suggests that people tend to classify themselves into categories based on several factors such as the organizations they work for (Ashforth \& Mael, 1989). Also, O'Reilly and Chatman (1986) suggest three dimensions of organizational commitment, including the identification dimension, which asserts that employees strive to maintain a relationship with organizations that have positive environments and values (Jones \& Volpe, 2011). Likewise, Vroom (1966) posits that employees prefer to work for organizations that enable them to achieve their goals and maximize their potential. Moreover, as an organization develops its identity as an innovative organization, employees tend to consider the reward they get by being a member of such an organization when making job-related decisions. This is also supported by the expectancy theory, which suggests that individuals are usually attracted to organizations that are perceived to have greater outcomes (Turban, Forret, \& Hendrickson, 1998).

In summary, innovative organizations usually have working conditions that, according to the literature, are viewed more favorably by knowledge workers. Those conditions collectively form a unique culture that represents most innovative organizations. This culture tends to serve as a motivating factor for workers to stay with the organization. Hence:

Proposition 1: Knowledge workers in innovative organizations are less likely to leave their jobs than those in non-innovative organizations.

While knowledge workers are less likely to leave innovative organizations, I argue that their level of commitment to their innovative organizations depends partially on individual differences. In the following section, I draw from the Big-Five model (Goldberg, 1990) to discuss the role of workers' personality as a factor that affects their decisions to leave innovative organizations.

\subsection{Individual Differences and Knowledge Workers Mobility}

Ample research has discussed how personality affects individuals' behaviors in job-related situations (e.g. Le et al, 2011; Judge et al, 2013; Zimmerman, 2008). The underlying assumption stems from the concept of person-organization from interactional psychology (O’Reilly, Chatman, \& Caldwell, 1991). The person-organization fit is defined as the match between the characteristics of individual personality and organizational climate (Kristof, 1996; Tom, 1971). Personality involves individuals' stable and innate mental structures that provide general direction for their choices and behaviors (Hogan, 1991; 2007). Early theories of vocational choice (e.g., Holland, 1966; Super, 1953) also support the interaction between personality and job choice. For example, Holland (1966) posits that the choice of a vocation is an expression of personality, whereas Super (1953) views a person's career as a function of the person's self-concept and the realities of the environment provided by the organization. A study by Judge and Bretz (1992) also found that organizational values were an important determinant of job choices.

The impact of personality on job-related outcomes is further supported by Schneider (1987, p. 447), which suggests that personality measures "should be useful for identifying the types of people who cluster in different organizations." Early research asserts that individuals are attracted to organizations that have a personality similar to their own (Judge \& Bretz, 1992; Tom, 1971). In contrary, Lee et al (1999) posit that a "shock" occurs when an employee finds that the actual environment inside the organization he works for is incompatible with 
his personality and his own values, arguing that such a shock triggers the thought of leaving the organization. The person-organization fit has also been found to be a significant predictor of job satisfaction (Resick, Baltes, \& Shantz, 2007). The aforementioned arguments suggest that an individual's decision to work or stay with an organization is significantly affected by his personality and how it fits the organization he/she works for. In the present paper, the concept of person-organization fit suggests that knowledge workers with traits similar to those of innovative organizations are more likely to stay with such organizations.

The Big five model is a common framework in studying personality (Costa \& McCrae, 1992; Goldberg, 1990). The five factors of the model are: (1) Extraversion, which describes the tendency to be sociable, assertive, active, directive and spontaneous, (2) Agreeableness, which represents the tendency to be likable, cheerful, adaptable, and cooperative, (3) Conscientiousness, which captures measures of achievement and dependability, (4) Neuroticism, which reflects the tendency to exhibit poor emotional adjustment and experience negative effects such as fear and anxiety, and (5) Openness to experience, which represents the tendency to be curious, creative, nonconforming, and autonomous. The five factors have been much examined in the literature of person-organization fit and various job-related variables. For example, Judge and Cable (1997) utilize it to investigate how applicants with high scores in those factors are attracted to different organizational cultures. Also, Le et al. (2011) find curvilinear relationships between personality traits, including Conscientiousness and Emotional Stability, and job performance. Research also finds the five factors to be related to individuals' career success (Ng, Eby, Sorensen, \& Feldman, 2005). Resick et al. (2007) also finds that the fit between workers' personality and organizations is strongly related to job satisfaction and job choice intentions. Research shows that the five traits interact with job scope to predict workers' creativity (Raja and Johns, 2010). As for worker mobility, a meta-analysis by Zimmerman (2008) concludes that the big five model affects employees turnover and intentions to quit. In this paper, I build on the big-five model as well to discuss how personality traits of knowledge workers impact their decision to leave innovative organizations.

\subsubsection{Extraversion}

Extroverts are sociable, assertive, bold, and spontaneous (Goldberg, 1990; Wiggins, 1996). The literature of innovation suggests that collaboration among functional units is critical to innovate (Berry, 2014; Teece, 1996). Sociable knowledge workers are more likely to succeed in innovative organizations where they need to cooperate with workers from various departments. Also, the assertiveness and boldness natures of extroverts reflect an aggressive personality, which matches the natures of innovators, who continuously innovate and develop new technologies that cause discontinuity and disruptions in the market (Christensen, 1997; Dosi, 1982). Moreover, Galbraith (1982) argues that "champions" of innovation are individuals inside the organization who spontaneously come up with new ideas. As suggested by earlier research, aggressive individuals are likely attracted to aggressive organizations (O'Reilly et al., 1991). On the other hand, workers who score low on extraversion might find difficulty in coping with innovative organizations due to lack of fit between their personality and the organization's. Thus:

Proposition 2: Extraversion affects knowledge workers' decision to leave an innovative organization in such a way that knowledge workers with higher score in extraversion are less likely to leave an innovative than those with lower score.

\subsubsection{Agreeableness}

Agreeable individuals are dependent and prefer to avoid conflicts (Costa and McCrae, 1992). Zimmerman (2008) concludes that agreeable individuals are less likely to leave their jobs because they tend to respect their contractual obligations. However, the literature also shows that agreeableness is associated with passivity and conformance (Costa and McCrae, 1992; Judge \& Cable, 1997). Thus, research suggests that agreeableness is negatively related to aggression (Zuckerman, Kuhlman, Joireman, \& Teta, 1993). As mentioned above, innovative organizations strive aggressively to differentiate themselves in competitive markets (Porter, 1985; Sirmon, Hitt, Ireland, \& Gilbert, 2011). The environment in innovative organizations is one that encourages creativity and generation of unique ideas that usually are not supported or agreed upon by the majority. According to the person-organization fit, individuals with high score in agreeableness have different personality than that of innovative organizations.

Proposition 3: Agreeableness affects knowledge workers' decision to leave an innovative organization in such a way that knowledge workers with higher score in agreeableness are more likely to leave an innovative than those with lower score. 


\subsubsection{Conscientiousness}

Research shows that conscientious individuals are cautious and risk-averse (Costa \& McCrae, 1992). O'Reilly et al (1991) assert that those characteristics are not compatible with innovative cultures, which value risk-taking. Innovators do not fear failure and they continue to try new ideas till they find implementable and promising ones (Galbraith, 1982). Further, conscientious individuals tend to be controlled, rule-bound, and have a need for order (Goldberg, 1990). Research shows that need for order is negatively related to innovation (Diener, Larsen, \& Emmons, 1984). Additionally, Hamel and Breen (2007) argue that organizations with controlled systems are less innovative than those with more freedom given to employees. As for conscientious individuals in the workplace, Judge and Cable (1997) find that individuals scoring high in conscientiousness are less attracted by innovative cultures. Feist (1998) also concludes that there is a negative relationship between conscientiousness and creativity. In a meta-analytic research, Zimmerman (2008) finds a negative relationship between conscientiousness and turnover, in general, because conscientious individuals are usually risk-averse and have the fear of losing their jobs. However, I argue that the relationship is more likely to be positive in innovative organizations due to lack of personality fit between employees and the innovative organization. To explain, conscientious knowledge workers would be under the risk of getting fired when their innovative organizations realize that those workers are not aggressive enough and are not generating new innovative ideas. Thus, because they tend to fear losing their jobs, conscientious knowledge workers might find more job security in less aggressive organizations.

Proposition 4: Conscientiousness affects knowledge workers' decision to leave an innovative organization in such a way that knowledge workers with higher score in conscientiousness are more likely to leave an innovative than those with lower score.

\subsubsection{Neuroticism}

Neurotic individuals are likely to be rigid and un-adaptable (Goldberg, 1990; Wiggins, 1996). On the other hand, research suggests that innovative organizations are far from rigidity and stability (O'Reilly et al, 1991). Indeed, it has been shown that innovation is associated with dynamic and continuous changes (Anderson and Tushman, 1990; Dosi, 1982). As a result, knowledge workers in innovative organization are continuously challenged to generate new ideas and to develop new technologies. Previous research supports the notion that individuals who score high in neuroticism are prone to fear and anxiety in novel situations (Judge and Cable, 1997; Wiggins, 1996), which contradicts what innovative organizations require in their employees. Actually, knowledge workers in innovative organizations are given permission to fearlessly try new ideas with the belief that one of those ideas could be the next innovation (Galbraith, 1982; Hamel and Breen, 2007). The arguments above indicate that the match between neurotic individuals and innovative organizations is not existent.

Proposition 5: Neuroticism affects knowledge workers' decision to leave an innovative organization in such a way that knowledge workers with higher score in neuroticism are more likely to leave an innovative than those with lower score.

\subsubsection{Openness to Experience}

Those who are open to experience tend to be imaginative, unconventional, and creative (Costa and McCrae, 1992; Goldberg, 1990). Research shows that openness to experience is associated with creativity and divergent thinking (George and Zhou, 2001; McCrae, 1987; Shalley, Zhou, and Oldham, 2004). Innovators are creative individuals who strive to generate new ideas. To develop new products, organizations must go through new experiences whether via the use of new technologies or new markets (Afuah, 2003). Furthermore, openness to experience implies characteristics such as willingness to change and autonomy (Judge and Cable, 1997). The literature shows a positive relationship between willingness to change and innovation in dynamic environments (Anderson and Tushman, 1990; Dosi, 1982). As individuals usually make the place they work at (Schneider, 1987), innovative organizations build on the individual creativity of their employees (Woodman, Sawyer, and Griffin, 1993). On the other hand, individuals who are not open to experience lack the motive to explore new ideas (Baer and Oldham, 2006). They do not have the mentality of organizations that strive to innovate continuously. Thus, whereas openness to experience might be associated generally with high turnover (Zimmerman, 2008), I propose that innovative organizations are thought to be favored by individuals who are open to experience. This leads to the following:

Proposition 6: Openness to experience affects knowledge workers' decision to leave an innovative organization in such a way that knowledge workers with higher score in openness to experience are less likely to leave an innovative than those with lower score 


\section{Discussion}

In this paper, I discussed knowledge workers mobility in innovative organizations. I argued that knowledge workers in innovative organizations are less likely to quit due to the favorable working conditions in such organizations. The literature suggests that innovative organizations have a structure characterized by decentralization and much freedom for employees to be creative (Galbraith, 1982; Hamel and Breen, 2007; Lertxundi et al, 2019). This type of structure allows for more creative thinking and shows more tolerance for failure, in order to keep employees motivated to generate the idea that could be implemented. Innovative organizations usually provide their employees with intensive technical training programs to keep up with evolving technologies (Chow and Gong 2010). They also have unique reward systems in which employees are rewarded for the value they create thorough their ideas (Hamel and Breen, 2007). Those conditions tend to be valued by employees when they make job-related decisions such as quitting.

Another contribution of the paper is addressing individual differences and their impact on knowledge workers mobility in innovative organizations. To explain, vocational choice theories suggest that individuals prefer to work for organizations that have personalities like their own (Holland, 1966). I provided argument based on the person-organization concept to suggest that employees are more likely to leave an organization when the fit between them and the organization they work for is weak. I argued that the decision to leave an innovative organization is impacted by knowledge workers' personalities.

Following the Big-Five model, the paper investigated how knowledge workers with different personalities feel about being members of an innovative organization. Particularly, I suggested that extroverts, characterized by assertiveness and risk-taking, are more attached to organizations that are aggressively innovating in competitive markets. Hence, they are less likely to leave such organizations. I also discussed how individuals with high score in agreeableness are less attracted by the working conditions of innovative organizations. Agreeable individuals are passive and tend to avoid conflict, which contradicts the characteristic of innovators (Costa and McCrae, 1992). As for conscientious individuals, described as cautions and risk-averse, previous research found a negative relationship between conscientious individuals and innovation. I asserted that conscientious individuals are more likely to leave innovative organizations than others. I further predicted that neurotic knowledge workers are less committed to innovative organizations because neurotic individuals tend to be rigid and prone to fear in novel situations (Goldberg, 1990; Wiggins, 1996). Finally, because innovation is all about experiencing new ideas or processes, knowledge workers who are open to new experiences are expected to value the environment in innovative organizations and therefore, are less likely to leave.

\subsection{Managerial implications}

The paper offers multiple implications for organizations. First, organizations should provide positive working environments and design flexible HR systems to motivate their knowledge workers. Research has shown that employees, in general, are less likely to leave an organization with encouraging internal environment (Arthur, 1994). With the increasing competition for talented workers (Gubman, 1998), organizations cannot afford to lose competent employees, knowing that having such employees gives them a competitive advantage (Pfeffer, 1994; Porter, 1985).

Second, while innovation is important for organizations to foster their strategic position in competitive markets, managers should take advantage of other benefits of innovation beyond its immediate impact. One important outcome that could be affected by innovativeness is organizational attractiveness. To illustrate, organizational innovation has an impact on an organization's image. According to signaling theory, organizational image is viewed as a signal for outsiders about the internal environment of the organization (Rynes, 1991). Applicants see organizations with positive images as more attractive, whereas organizations with negative images raise some concerns about their working conditions and, hence, are less likable by future applicants (Gatewood, Gowen, \& Lautenschlager, 1993).

Finally, human resource managers are encouraged to focus more on personality characteristics of applicants when recruiting. Besides the obvious benefit of finding the right personnel that match the values and culture of an organization, studying the personality of applicants in the selection process helps organizations to eventually reduce employees' voluntary turnover (Barrick \& Zimmerman, 2005). Research asserts that individuals who fit with the organization's culture are more likely to remain with the organization, while those with personalities different than those of their employers are more likely to quit (Lee et al., 1999). Hence, selecting individuals who possess personalities that fit with an organization's identity is of high strategic importance. 


\subsection{Future Research}

Although this paper attempts to fill some gaps in the literatures of knowledge workers mobility, voluntary turnover, strategic human resource management, and innovation, several areas of research need to be further explored. First, an empirical test of the propositions developed in this paper should give a better idea about their validity. Second, to better understand knowledge workers mobility, future research could examine other, individual, organizational, or environmental contingency factors that could impact knowledge workers mobility. At the organizational level, for instance, scholars could investigate knowledge workers mobility in organizations of different natures. For example, instead of differentiating themselves, some organizations prefer to be low-cost providers (Porter, 1985). In competitive markets, low-cost providers can compete mostly by cutting costs in order to deliver affordable products to customers. Researchers could examine whether this type of organizations have lower rates of workers mobility because workers, especially those with high social values, might prefer to be associated with such organizations. On the other hand, to be able to provide such affordable products, organizations must save money in other areas, including offering lower salaries for their employees. An argument could be made that such organizations might have higher rates of knowledge workers mobility due to their dissatisfaction with pay (Currall, Towler, Judge, \& Kohn, 2005; Rynes et al., 2004).

Finally, as a contribution to the personality literature, future research could also pursue a longitudinal study to examine whether an organization with workers of matching personality are more successful than others. Previous research suggests that applicants are attracted to organizations that have similar personalities (Holland, 1966; Judge \& Cable, 1997). Other research found that individuals who work for matching organizations have higher career success (Ng et al, 2005). However, it would be interesting to see if those results hold true when the assumption is looked at from the organizations' perspective. That is, to examine whether organizations with matching employees achieve higher performances in the long term.

\section{Conclusion}

The paper contributes to the literatures of knowledge workers mobility, voluntary turnover, strategic human resource management, and innovation, by increasing our understanding on knowledge workers mobility in innovative organizations. Previous research has examined individual and organizational factors that predict employees' mobility or voluntary turnover, in general. In this paper, I argue that innovative organizations have unique environments that, generally, increase workers' commitment and reduce workers' mobility. Furthermore, I utilize the Big-Five model to specifically predict the impact of workers' personalities on their decisions to leave an innovative organization or not. Despite the growing body of research on knowledge workers mobility, researchers are encouraged to further investigate multiple unexplored areas in the literature.

\section{References}

Abbas, M., Raja, U., Darr, W., \& Bouckenooghe, D. (2014). Combined effects of perceived politics and psychological capital on job satisfaction, turnover intentions, and performance. Journal of Management, 40, 1813-1830. https://doi.org/10.1177/0149206312455243

Afuah, A. (2003). Innovation Management: Strategies, Implementation, and Profits. New York, NY: Oxford University Press.

Alvesson, M. (2000). Social Identity and the Problem of Loyalty in Knowledge-Intensive Companies. Journal of Management Studies, 37, 1101-1124. https://doi.org/10.1111/1467-6486.00218

Anderson, P., \& Tushman, M. L. (1990). Technological discontinuities and dominant designs: a cyclical model of technological change. Administrative Science Quarterly, 35, 604-633. https://doi.org/10.2307/2393511

Arthur, J. B. (1994). Effects of human resource systems on manufacturing performance and Turnover. Academy of Management Journal, 37, 70-687. https://doi.org/10.5465/256705

Ashforth, B., \& Mael, F. (1989). Social identity theory and the organization. Academy of Management Review, 14, 20-39. https://doi.org/10.5465/amr.1989.4278999

Baer, M., \& Oldham, G. R. (2006). The curvilinear relation between experienced creative time pressure and creativity: moderating effects of openness to experience and support for creativity. Journal of Applied Psychology, 91, 963-970. https://doi.org/10.1037/0021-9010.91.4.963

Barney, J. (1991). Firm resources and sustained competitive advantage. Journal of Management, 17, 99-120. https://doi.org/10.1177/014920639101700108

Barrick, M., \& Zimmerman, R. (2005). Reducing voluntary, avoidable turnover through selection. Journal of Applied Psychology, 90, 159-166. https://doi.org/10.1037/0021-9010.90.1.159 
Berry, H. (2014). Global integration and innovation: Multicountry knowledge generation within MNCs. Strategic Management Journal, 35, 869-890. https://doi.org/10.1002/smj.2140

Bretz Jr, R. D., \& Judge, T. A. (1994). The role of human resource systems in job applicant decision processes. Journal of Management, 20, 531-551. https://doi.org/10.1016/0149-2063(94)90001-9

Bretz, R. D., Ash, R. A., \& Dreher, G. F. (1989). Do people make the place? An examination of the attraction-selection-attrition hypothesis. Personnel Psychology, 42, 561-581. https://doi.org/10.1111/j.1744-6570.1989.tb00669.x

Carsten, J. M., \& Spector, P. E. (1987). Unemployment, job satisfaction, and employee turnover: A meta-analytic test of the Muchinsky model. Journal of Applied Psychology, 72, 374-381. https://doi.org/10.1037/0021-9010.72.3.374

Chow, I. H. S., \& Gong, Y. (2010). The linkage of HRM and knowledge-related performance in China's technology-intensive industries. The International Journal of Human Resource Management, 21, 1289-1306. https://doi.org/10.1080/09585192.2010.483854

Christensen, C. M. (1997). The Innovator's Dilemma. When New Technologies Cause Great Firms to Fail. Boston, MA.: Harvard Business School Press.

Cohen, W. M., \& Levinthal, D. A. (1990). Absorptive capacity: A new perspective on learning and innovation. Administrative Science Quarterly, 35, 128-152. https://doi.org/10.2307/2393553

Collins, C. J., \& Smith, K. G. (2006). Knowledge exchange and combination: The role of human resource practices in the performance of high-technology firms. Academy of Management Journal, 49, 544-560. https://doi.org/10.5465/amj.2006.21794671

Corredoira, R. A., \& Rosenkopf, L. (2010). Should auld acquaintance be forgot? The reverse transfer of knowledge through mobility ties. Strategic Management Journal, 31, 159-181. https://doi.org/10.1002/smj.803

Costa P. T., \& McCrae, R. R. (1992). Revised NEO personality inventory and NEO five-factor inventory professional manual. Odessa, FL: Psychological Assessment Resources.

Currall, S., Towler, A., Judge, T., \& Kohn, L. (2005). Pay satisfaction and organizational outcomes. Personnel Psychology, 58, 613-640. https://doi.org/10.1111/j.1744-6570.2005.00245.x

Damanpour, F. (1991). Organizational innovation: A meta-analysis of effects of determinants and moderators. Academy of Management Journal, 34, 555-590. https://doi.org/10.5465/256406

Denison, D. R., \& Mishra, A. K. (1995). Toward a theory of organizational culture and effectiveness. Organization Science, 6, 204-223. https://doi.org/10.1287/orsc.6.2.204

Diener, E., Larsen, R. J., \& Emmons, R. A. (1984). Person X situation interactions: choice of situations and congruence response models. Journal of Personality and Social Psychology, 47, 580-592. https://doi.org/10.1037/0022-3514.47.3.580

Dong, L., Mitchell, T. R., Lee, T., Holtom, B., \& Hinkin, T. (2012). When employees are out of step with coworkers: How job satisfaction trajectories and dispersion influence individual- and unit-level voluntary turnover. Academy of Management Journal, 55, 1360-1380. https://doi.org/10.5465/amj.2010.0920

Dosi, G. (1982). Technological paradigms and technological trajectories. Research Policy, 11, 147-162. https://doi.org/10.1016/0048-7333(82)90016-6

Dougherty, D., \& Hardy, C. (1996). Sustained product innovation in large, mature organizations: Overcoming innovation-to-organization problems. Academy of Management Journal, 39, 1120-1153. https://doi.org/10.2307/256994

Eckardt, R., Skaggs, B. C., \& Youndt, M. (2014). Turnover and Knowledge Loss: An Examination of the Differential Impact of Production Manager and Worker Turnover in Service and Manufacturing Firms. Journal of Management Studies, 51, 1025-1057. https://doi.org/10.1111/joms.12096

Feist, G. J. (1998). A meta-analysis of personality in scientific and artistic creativity. Personality and Social Psychology Review, 2, 290-309. https://doi.org/10.1207/s15327957pspr0204_5

Galbraith, J. R. (1982). Designing the innovating organization. Organizational Dynamics, 10, 5-25. https://doi.org/10.1016/0090-2616(82)90033-X

Gatewood, R. D., Gowan, M. A., \& Lautenschlager, G. J. (1993). Corporate image, recruitment image, and initial 
job choice decisions. Academy of Management Journal, 36, 414-427. https://doi.org/10.2307/256530

George, J. M., \& Zhou, J. (2001). When openness to experience and conscientiousness are related to creative behavior: An interactional approach. Journal of Applied Psychology, 8, 513-524. https://doi.org/10.1037/0021-9010.86.3.513

Goldberg, L. R. (1990). An alternative" description of personality": The big-five factor structure. Journal of Personality and Social Psychology, 59, 1216-1230. https://doi.org/10.1037/0022-3514.59.6.1216

Griffeth, R. W., Hom, P. W., \& Gaertner, S. (2000). A meta- analysis of antecedents and correlates of employee turnover: Update, moderator tests, and research implications for the millennium. Journal of Management, 26, 463-488. https://doi.org/10.1177/014920630002600305

Gubman, E. J. (1998). The talent solution. New York, NY: McGraw-Hill.

Guthrie, J. P. (2001). High-involvement work practices, turnover, and productivity: Evidence from New Zealand. Academy of Management Journal, 44, 180-190. https://doi.org/10.2307/3069345

Hamel, G., \& Breen, B. (2007). The future of management. Boston, MA: Harvard Business Press.

Hancock, J. I., Allen, D. G., Bosco, F. A., McDaniel, K. R., \& Pierce, C. A. (2013). Meta-analytic review of employee turnover as a predictor of firm performance. Journal of Management, 39, 573-603. https://doi.org/10.1177/0149206311424943

Hogan, R. (1991). Personality and personality assessment. In Dunnette, M. D. \& Hough, L. M. (Eds.), Handbook of industrial and organizational psychology (2nd ed., Vol. 2, pp. 873-919). Palo Alto, CA: Consulting Psychologists Press.

Hogan, R. (2007). Personality and the fate of organizations. Lawrence Erlbaum Associates Publishers.

Holland, J. L. (1973). Making vocational choices: A theory of careers. Englewood Cliffs, NJ: Prentice-Hall.

Howell. I. M., \& Higgins, C. A. (1990). Champions of change: Identifying, understanding, and supporting champions of technological innovations. Organizational Dynamics, 19, 40-55. https://doi.org/10.1016/0090-2616(90)90047-S

Huselid, M. A. (1995). The impact of human resource management practices on turnover, productivity, and corporate financial performance. Academy of Management Journal, 38, 635-672. https://doi.org/10.2307/256741

Jones, C., \& Volpe, E. H. (2011). Organizational identification: Extending our understanding of social identities through social networks. Journal of Organizational Behavior, 32, 413-434. https://doi.org/10.1002/job.694

Judge, T. A., \& Bretz, R. D. (1992). Effects of work values on job choice decisions. Journal of Applied Psychology, 77, 261-271. https://doi.org/10.1037/0021-9010.77.3.261

Judge, T. A., \& Cable, D. M. (1997). Applicant personality, organizational culture, and organization attraction. Personnel Psychology, 50, 359-394. https://doi.org/10.1111/j.1744-6570.1997.tb00912.x

Judge, T. A., Rodell, J. B., Klinger, R. L., Simon, L. S., \& Crawford, E. R. (2013). Hierarchical representations of the five-factor model of personality in predicting job performance: Integrating three organizing frameworks with two theoretical perspectives. Journal of Applied Psychology, 98, 875-925. https://doi.org/10.1037/a0033901

Kogut, B., \& Zander, U. (1992). Knowledge of the firm, combination capabilities, and the replication of technology. Organization Science, 3, 383-397. https://doi.org/10.1287/orsc.3.3.383

Kristof, A. L. (1996). Person-organization fit: An integrative review of its conceptualizations, measurement, and implications. Personnel Psychology, 49, 1-49. https://doi.org/10.1111/j.1744-6570.1996.tb01790.x

Kwon, K., Chung, K., Roh, H., Chadwick, C., \& Lawler, J. J. (2012). The moderating effects of organizational context on the relationship between voluntary turnover and organizational performance: Evidence from Korea. Human Resource Management, 51, 47-70. https://doi.org/10.1002/hrm.20433

Le, H., Oh, I. S., Robbins, S. B., Ilies, R., Holland, E., \& Westrick, P. (2011). Too much of a good thing: curvilinear relationships between personality traits and job performance. Journal of Applied Psychology, 96, 113-133. https://doi.org/10.1037/a0021016

Lee, J., Chiang, F. F., Van Esch, E., \& Cai, Z. (2018). Why and when organizational culture fosters affective commitment among knowledge workers the mediating role of perceived psychological contract fulfilment 
and moderating role of organizational tenure'. The International Journal of Human Resource Management, 29, 1178-1207. https://doi.org/10.1080/09585192.2016.1194870

Lee, T. W., Mitchell, T. R., Holtom, B. C., McDaniel, L., \& Hill, J. W. (1999). Theoretical development and extension of the unfolding model of voluntary turnover. Academy of Management Journal, 42, 450-462. https://doi.org/10.5465/257015

Lertxundi, A., Barrutia, J., \& Landeta, J. (2019). Relationship between innovation, HRM and work organisation. An exploratory study in innovative companies. International Journal of Human Resources Development and Management, 19, 183-207. https://doi.org/10.1504/JJHRDM.2019.098628

March, J., \& Simon, H. (1958). Organizations. New York, NY: Wiley.

McClean, E., \& Collins, C. J. (2011). High-commitment HR practices, employee effort, and firm performance: Investigating the effects of HR practices across employee groups within professional services firms. Human Resource Management, 50, 341-363.

McCrae, R. R., \& Costa, P. T., Jr. (1987). Validation of the five-factor model of personality across instruments and observers. Journal of Personality and Social Psychology, 52, 81-90. https://doi.org/10.1037/0022-3514.52.1.81

Mihalache, O. R., Jansen, J. J., Van Den Bosch, F. A., \& Volberda, H. W. (2012). Offshoring and firm innovation: The moderating role of top management team attributes. Strategic Management Journal, 33, 1480-1498. https://doi.org/10.1002/smj.1983

Mitchell, T. R., Holtom, B. C., \& Lee, T. W. (2001). How to keep your best employees: The development of an effective attachment policy. Academy of Management Executive, 15, 96-108. https://doi.org/10.5465/ame.2001.5897929

Ng, T. W., Eby, L. T., Sorensen, K. L., \& Feldman, D. C. (2005). Predictors of objective and subjective career $\begin{array}{lllll}\text { success: } & \text { A meta-analysis. Personnel }\end{array}$ https://doi.org/10.1111/j.1744-6570.2005.00515.x

Nonaka, I. (1994). A dynamic theory of organizational knowledge creation. Organization Science, 5, 14-37. https://doi.org/10.1287/orsc.5.1.14

Nyberg, A. J., \& Ployhart, R. E. (2013). Context-emergent theory of human capital. Academy of Management Review, 38, 109-131. https://doi.org/10.5465/amr.2011.0201

O'Reilly, C. A., Chatman, J., \& Caldwell, D. F. (1991). People and organizational culture: A profile comparison approach to assessing person-organization fit. Academy of Management Journal, 34, 487-516. https://doi.org/10.2307/256404

O'Reilly, C. A. (1991). 'Organizational behavior: Where we've been, where we're going. In M. Rosenzweig, R. and Porter, L. W. (Eds.), Annual Review of Psychology (Vol. 17, pp. 427-458). Palo Alto, CA: Annual Reviews. https://doi.org/10.1037/0021-9010.71.3.492

O'Reilly, C. A., \& Chatman, J. (1986). Organizational commitment and psychological attachment: The effects of compliance, identification, and internalization on prosocial behavior. Journal of Applied Psychology, 71, 492-499. https://doi.org/10.1037/0021-9010.71.3.492

Pfeffer, J. (1994). Competitive advantage through people. California Management Review, 36, 9-28. https://doi.org/10.2307/41165742

Phillips, D. J. (2002). A genealogical approach to organizational life chances: The parent-progeny transfer among Silicon Valley law firms, 1946-1996. Administrative Science Quarterly, 47, 474-506. https://doi.org/10.2307/3094848

Polanyi, M. (1962). Personal Knowledge: Towards a Post-Critical Philosophy. New York, NY: Harper \& Row.

Porter, M. E. (1985). Competitive Advantage. New York, NY: Free Press.

Reilly, G., A. Nyberg, M. M., \& Weller, I. (2014). Human Capital Flows: Using Context-Emergent Turnover (CET) Theory to explore the process by which turnover, hiring and job demands affects patient satisfaction. Academy of Management Journal, 57, 766-790. https://doi.org/10.5465/amj.2012.0132

Resick, C. J., Baltes, B. B., \& Shantz, C. W. (2007). Person-organization fit and work-related attitudes and decisions: examining interactive effects with job fit and conscientiousness. Journal of Applied Psychology, 92, 1446-1455. https://doi.org/10.1037/0021-9010.92.5.1446 
Rosenkopf, L., \& Almeida, P. (2003). Overcoming local search through alliances and mobility. Management Science, 49, 751-766. https://doi.org/10.1287/mnsc.49.6.751.16026

Rynes, S. L. (1991). Recruitment, job choice, and post-hire consequences: A call for new research directions. In Dunnette, M. D. \& Hough, L. M. (Eds.), Handbook of industrial and organizational psychology (2nd ed., Vol. 2, pp. 399-444). Palo Alto, CA: Consulting Psychologists press.

Rynes, S. L., Gerhart, B., \& Minette, K. A. (2004). The importance of pay in employee motivation: Discrepancies between what people say and what people do. Human Resource Management, 43, 381-394. https://doi.org/10.1002/hrm.20031

Schneider B. (1987). The people make the place. Personnel Psychology, 40, 437-453. https://doi.org/10.1111/j.1744-6570.1987.tb00609.x

Shalley, C. E., Zhou, J., \& Oldham, G. R. (2004). The effects of personal and contextual characteristics on creativity, Where should we go from here? Journal of Management, 30, 933-958. https://doi.org/10.1016/j.jm.2004.06.007

Shaw, J. D., Delery J. E., Jenkins, G. D., \& Gupta, N. (1998). An organization-level analysis of voluntary and involuntary turnover. Academy of Management Journal, 41, 511-525. https://doi.org/10.2307/256939

Sheridan. J. E (1992). Organizational culture and employee retention. Academy of Management Journal, 35, 1036-1056. https://doi.org/10.2307/256539

Sirmon, D. G., Hitt, M. A., Ireland, R. D., \& Gilbert, B. A. (2011). Resource orchestration to create competitive advantage breadth, depth, and life cycle effects. Journal of Management, 37, 1390-1412. https://doi.org/10.1177/0149206310385695

Song, J., Almeida, P., \& Wu, G. (2003). Learning-by-Hiring, When Is Mobility More Likely to Facilitate Interfirm Knowledge Transfer? Management Science, 49, 351-365. https://doi.org/10.1287/mnsc.49.4.351.14429

Super, D. E. (1953). A theory of vocational development. American Psychologist, 8,185-190. https://doi.org/10.1037/h0056046

Teece, D. (1996). Firm organization, industrial structure, and technological innovation. Journal of Economic Behavior and Organization, 31, 193-224. https://doi.org/10.1016/S0167-2681(96)00895-5

Teece, D. J. (1986). Profiting from technological innovation, Implications for integration, collaboration, licensing and public policy. Research Policy, 15, 285-305. https://doi.org/10.1016/0048-7333(86)90027-2

Teece, D. J. (2006). Reflections on "profiting from innovation. Research Policy, 35, 1131-1146. https://doi.org/10.1016/j.respol.2006.09.009

Tom, V. R. (1971). The role of personality and organizational images in the recruiting process. Organizational Behavior and Human Performance, 6, 573-592. https://doi.org/10.1016/S0030-5073(71)80008-9

Tsai, W. (2001). Knowledge transfer in intra-organizational networks, Effects of network position and absorptive capacity on business-unit innovation and performance. Academy of Management Journal, 44, 996-1004. https://doi.org/10.2307/3069443

Turban, D. B., Forret, M. L., \& Hendrickson, C. L. (1998). Applicant attraction to firms, Influences of organization reputation, job and organizational attributes, and recruiter behaviors. Journal of Vocational Behavior, 52, 24-44. https://doi.org/10.1006/jvbe.1996.1555

Von Krogh, G., Ichijo, K., \& Nonaka, I. (2000). Enabling knowledge creation, How to unlock the mystery of tacit knowledge and release the power of innovation. New York, NY, Oxford university press.

Von Nordenflycht, A. (2010). What is a professional service firm? Toward a theory and taxonomy of knowledge-intensive firms. Academy of Management Review, 35,155-174. https://doi.org/10.5465/amr.35.1.zok155

Vroom, V. H. (1966). Organizational choice, a study of pre- and post decision processes. Organizational Behavior and Human Performance, 1, 212-225. https://doi.org/10.1016/0030-5073(66)90013-4

Wezel, F. C., Cattani, G., \& Pennings, J. M. (2006). Competitive implications of inter firm mobility. Organization Science, 17, 691-709. https://doi.org/10.1287/orsc.1060.0219

Wiggins, J. S. (1996). The five-factor model of personality, Theoretical perspectives. New York, USA, Guilford Press. 
Woodman, R. W., Sawyer, J. E., \& Griffin, R. W. (1993). Toward a theory of organizational creativity. Academy of Management Review, 18, 293-321. https://doi.org/10.5465/amr.1993.3997517

Wright, P. M., \& McMahan, G. C. (1992). Theoretical perspectives for strategic human resource management. Journal of Management, 18, 295-320. https://doi.org/10.1177/014920639201800205

Zimmerman, R. D. (2008). Understanding the impact of personality traits on individuals turnover decisions, A meta-analytic path model. Personnel Psychology, 61, 309-348. https://doi.org/10.1111/j.1744-6570.2008.00115.x

Zuckerman, M., Kuhlman, D. M., Joireman, J., Teta, P., \& Kraft, M. (1993). A comparison of three structural models for personality, The Big Three, the Big Five, and the Alternative Five. Journal of Personality and Social Psychology, 65, 757-768. https://doi.org/10.1037/0022-3514.65.4.757

\section{Copyrights}

Copyright for this article is retained by the author(s), with first publication rights granted to the journal.

This is an open-access article distributed under the terms and conditions of the Creative Commons Attribution license (http://creativecommons.org/licenses/by/4.0/). 